\title{
Influence of Appendectomy Timing in the Pathological Outcome and the Morbidity of Acute Appendicitis in Children: A Retrospective Study
}

\section{Zitouni H, Louati $H^{*}$, Nasri A, Ammar S, Dhaou MB, Jallouli M and Mhiri R}

Department of Pediatric Surgery, Hedi Chaker Hospital, Sfax, Tunisia

${ }^{*}$ Corresponding author: Hamdi Louati, Department of Pediatric Surgery, Hedi Chaker Hospital, Sfax, Tunisia, Tel: 0021652225719; E-mail: drhamdilouati85@yahoo.com

Received date: May 14, 2018; Accepted date: May 22, 2018; Published date: May 28, 2018

Citation: Zitouni H, Louati H, Nasri A, Ammar S, Dhaou MB, et al. (2018) Influence of Appendectomy Timing in the Pathological Outcome and the Morbidity of Acute Appendicitis in Children: A Retrospective Study. Arch Med Vol No:10 Iss No:3:6

Copyright: (c) 2018 Zitouni $\mathrm{H}$ et al. This is an open-access article distributed under the terms of the Creative Commons Attribution License, which permits unrestricted use, distribution, and reproduction in any medium, provided the original author and source are credited.

\section{Abstract}

Introduction: Surgery is indicated for acute appendicitis but there is controversy regarding precise timing for appendectomy.

Objective: Our aim was to evaluate the impact of time delay from emergency department presentation to surgery in developing complicated appendicitis in children and associated morbidity.

Methods: 540 charts of children, who underwent appendectomy, between January 2013 and December 2016 were retrospectively reviewed. Groups were divided by time of intervention. Group 1: less than $24 \mathrm{~h}(\mathrm{n}=209,38.7 \%)$, group 2: $24 \mathrm{~h}$ to $48 \mathrm{~h}(\mathrm{n}=293,54.5 \%)$, and group 3: greater than $48 \mathrm{~h}(\mathrm{n}=38,6.8 \%)$. We considered complicated appendicitis gangrenous, abscess or perforated appendix per operatively and on histopathologic examination. Statically analysis and was performed to search the predictors of complicated appendicitis and evaluate postoperative complications.

Results: Among 540 children included in the study, 164 $(30.4 \%)$ had complicated acute appendicitis. There was no correlation between delay to surgery and the risk of developing a complicated form of the disease for group 1 and Group 2. Beyond the $48^{\text {th }} \mathrm{h}$ (group 3), the rate of developing complicated appendicitis and post-operative complications increased significantly. Hospital stay was not affected by delayed surgery.

Conclusion: A short in-hospital delay before surgery less than $48 \mathrm{~h}$, for acute appendicitis in child, is not associated with an increased rate of complex appendicitis neither associated morbidity.

\section{Keywords Appendicitis; Delay surgery; Child; Complication; Morbidity}

\section{Introduction}

Acute appendicitis is the commonest pediatric abdominal surgical emergency. Although new trials suggest antibiotic therapy alone is sufficient for acute simple appendicitis, surgery remains the gold standard [1,2]. Recent studies suggest that after antibiotics therapy has been initiated, appendicitis can be managed with a semi elective strategy [3,4]. Some studies report that delayed appendectomy in the daytime may offer better work environment [5]. However, others report that it increases the risk of advanced pathological forms $[6,7]$. This study aims to evaluate the impact of interval of appendectomy in developing complex appendicitis and post-operative complications in children.

\section{Materials and Methods}

A retrospective review of all patients who underwent emergency appendectomy with the intention to treat clinically suspected appendicitis between January 2013 and December 2016 at our centre was undertaken. Demographic data, use of antibiotics before surgery, interval of appendectomy, surgical approach (open vs. laparoscopic), outcomes, pathological examination of appendix and hospital stay. Interval of appendectomy was defined as time from admission in the emergency department until time of incision. Complex appendicitis was defined as gangrenous, abscessed or perforated appendix on per operative findings and pathological examination.

The morbidity was evaluated by the length of hospital stay and post-operative complications. Post-operative complications were defined as development of surgical site infection, intraabdominal abscess, or sepsis until 30 days after discharge.

All patients were separated in 3 groups according to the interval of appendectomy. Group 1: less than $24 \mathrm{~h}$ ( $\mathrm{n}=209$, $38.7 \%)$, group 2: $24 \mathrm{~h}$ to $48 \mathrm{~h}(\mathrm{n}=293,54.5 \%)$, and group 3: greater than $48 \mathrm{~h}(\mathrm{n}=38,6.8 \%)$. Characteristics of patients who had simple appendicitis were compared with those who had complicated appendicitis. We estimated predictors of complicated appendicitis using. Association between surgical 
delay and the risk of developing complicated appendicitis and morbidity were studied. All tests were carried out using $p<0.05$ as the significance level.

\section{Results}

Between January 2013 and December 2016, 540 patients underwent appendicectomy with the intention to treat clinically suspected appendicitis at our centre. There were 309 male
(57.3\%) and 231 female (42.7\%). The Mean of age was $9.23 \pm$ 2.78 years. Of all patients, $316(58.5 \%)$ were presented simple appendicitis, 164 patients $(30.4 \%)$ had complicated appendicitis, and 60 patients $(11.1 \%)$ presented a normal appendix.

Differences between patients with simple and complex appendicitis are shown in Table 1 . Gender $(p=0.407)$, delay to operation $(p=0.096)$ and operative method $(p=0.973)$ were not correlated to complex appendicitis.

Table 1: Comparisons between patients with simple appendicitis and patients with complicated appendicitis.

\begin{tabular}{|c|c|c|c|c|c|}
\hline Characteristics of patients & \multicolumn{2}{|c|}{ Simple appendicitis (316) } & \multicolumn{2}{|c|}{ Complex appendicitis (164) } & p-value \\
\hline \multicolumn{6}{|l|}{ Gender } \\
\hline Male & 182 & $58.20 \%$ & 104 & $63.40 \%$ & 0.407 \\
\hline Female & 134 & $41.80 \%$ & 60 & $36.60 \%$ & \\
\hline \multicolumn{6}{|l|}{ Temperature $\geq 38.5^{\circ} \mathrm{C}$} \\
\hline Yes & 190 & $60.10 \%$ & 136 & $82.90 \%$ & $<0.001$ \\
\hline No & 126 & $39.90 \%$ & 28 & $17.10 \%$ & \\
\hline \multicolumn{6}{|l|}{ Operative method } \\
\hline Open & 233 & $73.80 \%$ & 120 & $73.20 \%$ & 0.973 \\
\hline Laparoscopic & 83 & $26.20 \%$ & 44 & $26.80 \%$ & \\
\hline \multicolumn{6}{|l|}{ Delay to operation } \\
\hline$<24 \mathrm{~h}$ & 127 & $40.20 \%$ & 57 & $34.70 \%$ & \\
\hline $24-48 \mathrm{~h}$ & 175 & $55.30 \%$ & 83 & $50.60 \%$ & 0.096 \\
\hline$>48 \mathrm{~h}$ & 14 & $4.50 \%$ & 24 & $14.70 \%$ & \\
\hline \multicolumn{6}{|l|}{ Antibiotics before surgery } \\
\hline Yes & 131 & $41.40 \%$ & 104 & $63.40 \%$ & 0.027 \\
\hline No & 185 & $58.60 \%$ & 60 & $36.60 \%$ & \\
\hline \multicolumn{6}{|l|}{ Post-operative complications } \\
\hline Yes & 11 & $3.40 \%$ & 23 & $14.00 \%$ & 0.003 \\
\hline No & 305 & $96.60 \%$ & 141 & $86.00 \%$ & \\
\hline \multicolumn{6}{|l|}{ Hospital stay (days) } \\
\hline$<=2 \mathrm{j}$ & 214 & $67.70 \%$ & 23 & $14.00 \%$ & \\
\hline$>2 \mathrm{j}$ & 102 & $32.30 \%$ & 141 & $86.00 \%$ & $<0.001$ \\
\hline
\end{tabular}

Patient with complex appendicitis received more ATB and had longer hospital stay in hospital. Temperature in admission $\geq$ $38.5^{\circ} \mathrm{C}$ was significantly associated with complicated appendicitis $(p<0.001)$.

Differences between patients who underwent surgery at $<24$, 24-48 and $>48 \mathrm{~h}$ are shown in Table 2 . Those with longer delays to operation were more likely to receive more antibiotics $(p<0.001)$. Hospital stay and post-operative complications were not significantly associated with delayed appendectomy $(p=0.735$ and $p=0.648$ respectively). There was also, no significant association between delay to operation and rate of complex appendicitis. When divided in three groups (Table 3 ), the rate of complex appendicitis increased significantly when surgery was done after $48 \mathrm{~h}$; group 1 [odds ratio $(O R)=0.786$, $p=0,362]$, group 2 [OR=0.849, $p=0.793$ ] and group 3 [OR=3.615, $p=0.023$. Also postoperative complications increased if child underwent surgery after $48 \mathrm{~h}$ from admission; group 1 
[OR=0.762, $\mathrm{p}=0.665]$, group $2[\mathrm{OR}=0.407, \mathrm{p}=0.142]$ and group 3

[OR=8.909, $p<0.001]$.

Table 2: Characteristics of Patients by the interval of appendectomy.

\begin{tabular}{|c|c|c|c|c|c|c|c|}
\hline Characteristics of patients & \multicolumn{2}{|c|}{$<24$ h (209) } & \multicolumn{2}{|c|}{$24-48$ h (293) } & \multicolumn{2}{|c|}{$>48 \mathrm{~h}(38)$} & p-value \\
\hline \multicolumn{8}{|l|}{ Gender } \\
\hline Male & 99 & $47.30 \%$ & 183 & $62.40 \%$ & 30 & $80 \%$ & 0.316 \\
\hline female & 110 & $52.70 \%$ & 110 & $37.60 \%$ & 8 & $20 \%$ & \\
\hline \multicolumn{8}{|l|}{ Operative method } \\
\hline Open & 150 & $71.80 \%$ & 221 & $75.40 \%$ & 28 & $73.60 \%$ & 0.691 \\
\hline Laparoscopic & 59 & $28.20 \%$ & 72 & $24.60 \%$ & 10 & $26.30 \%$ & \\
\hline \multicolumn{8}{|l|}{ Histology } \\
\hline Simple & 160 & $76.50 \%$ & 221 & $75.40 \%$ & 18 & $47.30 \%$ & 0.827 \\
\hline Complex & 49 & $23.30 \%$ & 72 & $24.60 \%$ & 20 & $52.70 \%$ & \\
\hline \multicolumn{8}{|l|}{ Antibiotics before surgery } \\
\hline Yes & 29 & $14 \%$ & 215 & $73.40 \%$ & 23 & $60 \%$ & $<0.001$ \\
\hline No & 280 & $86 \%$ & 78 & $26.60 \%$ & 15 & $40 \%$ & \\
\hline \multicolumn{8}{|l|}{ Post-operative complications } \\
\hline Yes & 10 & $4.80 \%$ & 10 & $3.40 \%$ & 13 & $34.20 \%$ & 0.648 \\
\hline No & 199 & $95.20 \%$ & 283 & $96.60 \%$ & 25 & $66.80 \%$ & \\
\hline \multicolumn{8}{|l|}{ Hospital stay (day) } \\
\hline$<=2 j$ & 85 & $40.60 \%$ & 135 & $46.40 \%$ & 28 & $73.60 \%$ & 0.735 \\
\hline$>2 \mathrm{j}$ & 124 & $59.40 \%$ & 157 & $53.60 \%$ & 10 & $26.30 \%$ & \\
\hline
\end{tabular}

Table 3: Correlation between delay to surgery and complicated appendicitis and correlation between delay to surgery and postoperative complications.

\begin{tabular}{|c|c|c|}
\hline Variables & OR & p-value \\
\hline \multicolumn{3}{|c|}{ Complex appendicitis } \\
\hline Group 1 (<24 h) & 0.786 & 0.362 \\
\hline Group 2 (24-48 h) & 0.849 & 0.793 \\
\hline Group 3 (>48 h) & 3,615 & 0.023 \\
\hline \multicolumn{3}{|c|}{ Post-operative complications } \\
\hline Group 1 (<24 h) & 0.762 & 0.665 \\
\hline Group 2 (24-48 h) & 0.407 & 0.142 \\
\hline Group 3 (>48 h) & 8.909 & $<0.001$ \\
\hline
\end{tabular}

\section{Discussion}

Acute appendicitis has been the commonest abdominal surgical emergency requiring operation for both adults and children. Age may be a potential for selection bias when study is interested by both adults and children. In fact, Hornbay et al. found that children underwent appendectomy more quickly than elderly because of difficulty of diagnosis in the aged group [8]. In another study, early intervention was most likely to be performed on younger patients with fewer pre-existing comorbidities [3]. In literature, only six pediatric studies were reported, correlating time to surgery with perforated rate. Results are controversial [9]. In this study, we report our own experience devoted only to pediatric population.

Some papers suggest that appendectomy should be considered as an urgent procedure to prevent complications and morbidity [10], especially in a developing country $[10,11]$. However, trials of successful no operative management of uncomplicated appendicitis have suggested that short delay before appendectomy may be feasible $[12,13]$. Although there is evidence to support delay of surgery, it is not well established what this interval should be. Some authors found that even short delays of 6 to $12 \mathrm{~h}$ may result on increasing surgical site infections [5]. Others found no increased rate of complicated appendicitis if time to operation was less than $48 \mathrm{~h}$ [6]. Brett et al. suggest that patients who are diagnosed with acute appendicitis at night can be managed no operatively until 
surgery can be scheduled at a more convenient time [3]. A study focusing on the pediatric population, confirmed the safety of delaying appendectomy until the following morning when patients are admitted late in the evening [14]. There was no association between surgical site infection rates and delayed surgery [14]. Our study supports a safe delay of appendectomy for children less than $48 \mathrm{~h}$.

For Shin et al. [15] clinical outcomes of delayed appendectomy were not superior to those of early appendectomy. Findings in Chen et al. study, demonstrated that delay of appendectomy more than $8 \mathrm{~h}$ after admission, did not increase the appendix perforation and postoperative complication rate [4]. Hornby et al. found that a delay to surgery less than $48 \mathrm{~h}$ does not influence the pathologic outcome of acute appendicitis [8]. Our study supports these findings and unlike Texiera et al. study [5], surgical site infection didn't increase if delayed surgery less than $48 \mathrm{~h}$.

The strengths of this study are that it focus on pediatric population, done in a developing country were disease presents generally late and reviewed at the same time the impact of interval off appendectomy on pathological outcomes and postoperative complications.

\section{Conclusion}

The main finding of our study was that a short delay of appendectomy less than $48 \mathrm{~h}$ does not increase rate of complex appendicitis neither morbidity even in children living in developing countries.

\section{References}

1. Styrud J, Eriksson S, Nilsson I, Ahlberg G, Haapaniemi S, et al. (2006) Appendectomy versus antibiotic treatment in acute appendicitis. A prospective multicenter randomized controlled trial. World J Surg 30: 1033-1037.

2. Varadhan K, Humes DJ, Neal KR, Lobo DN (2010) Antibiotic therapy versus ap-pendectomy for acute appendicitis: A meta-analysis. World J Surg 34: 199-209.

3. Ingraham AM, Cohen ME, Bilimoria KY, Ko CY, Hall BL, et al. (2010) Effect of delay to operation on outcomes in adults with acute appendicitis. Arch Surg 145: 886e92.
4. Brett A. F, John CK, Imke J, Jonathan AM, Keith WM,et al. (2015) The impact of operative timing on outcomes of appendicitis: A national surgical quality improvement project analysis. Am J Surg 209: 498-502.

5. Chen CC, Ting CT, Tsai MJ, Hsu WC, Chen PC, et al. (2015) Appendectomy timing: Will delayed surgery increase the complications?. J Chin Med Assoc 78: 395-399.

6. Bhangu A, Singh P, Panagiotopoulou I, Chatzizacharias N, Rana M, et al. (2014) Safety of short, in-hospital delays before surgery for acute appendicitis: Multicenter cohort study, systematic review, and meta-analysis. Ann Surg 259: 894-903.

7. Bickell N, Aufses Jr AH, Rojas M, Bodian C (2006) How time affects the risk of rupture in appendicitis. J Am Coll Surg 202: 401-406.

8. Hornby ST, Shahtahmassebi G, Lynch S, Ladwa N, Stell DA (2014) Delay to surgery does not influence the pathological outcome of acute appendicitis. Scand J Surg 103: 5-11.

9. William B, Jared B, Nadya T, Marybelle P, Ferrin D, et al. (2015) Impact of in-hospital timing to appendectomy on perforation rates in children with appendicitis. J Emerg Med: 1-8.

10. Kong VY, Bulajic B, Allorto NL, Handley J, Clarke DL (2012) Acute appendicitis in a developing country.World J Surg 36: 2068-2073.

11. Kong VY, Sartorius B, Clarke DL (2015) Acute appendicitis in the developing world is a morbid disease. Ann R Coll Surg Engl 97: 390-395.

12. Armstrong J, Merritt N, Jones S, Scott L, Butter A (2014) Nonoperative management of early, acute appendicitis in children: Is it safe and effective?. J Pediatr Surg 49: 782-785.

13. Varadhan KK, Neal KR, Lobo DN (2012) Safety and efficacy of antibiotics compared with appendicectomy for treatment of uncomplicated acute appendicitis: Meta-analysis of randomised controlled trials. BMJ 344: e2156.

14. Boomer LA, Cooper JN, Deans KJ, Minneci PC, Leonhart K, et al. (2014) Does delay in appendectomy affect surgical site infection in children with appendicitis?. J Pediatr Surg 49: 1026-1029.

15. Shin CS, Roh YN, Kim JI (2014) Delayed appendectomy versus early appendectomy in the treatment of acute appendicitis: A retrospective study. World J Emerg Surg 9: 8. 